\title{
Socio-Economic And Psychological Perspectives Of Female Crimes
}

\author{
Rana Saba Sultan \\ Department of Sociology \\ University of Karachi \\ Irshad Bibi \\ Department of Sociology \\ Islamia College, Karachi
}

\begin{abstract}
Until a few decades ago, crime was considered to be a predominantly male phenomenon, but as women increasingly joined the mainstream of society, their share in crime increased considerably the world over. The family unit has been torn apart because of economic necessity, increasing awareness of women's rights and the need to step out of home to reach the work place. In fact the growing rate of woman prisoners can be linked to social changes, especially in urbanization and new agents of social control such as urban police and moral reformers. The fewer job opportunities and lower wages for women resulted in economic marginalization and increased the need for women to resort to crimes such as prostitution, especially during wars, when men were not able to support their families. Prostitution was often, the most readily available way for women to support themselves and their children.
\end{abstract}

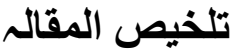

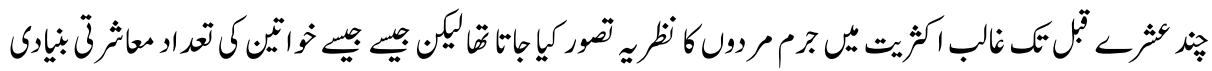

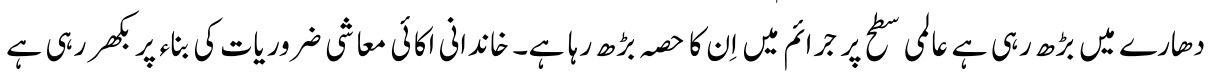

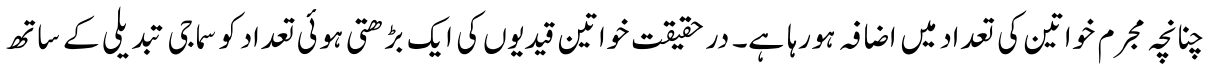

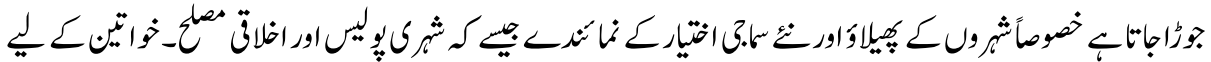

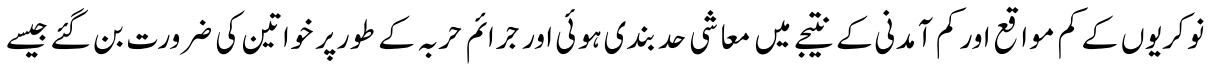

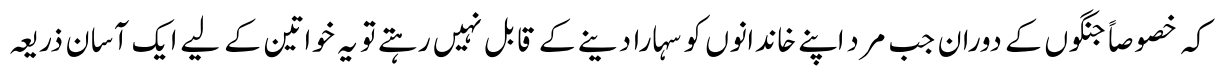
rوتأخ

\section{Introduction}

\section{Biological Perspective}

Cesare Lombroso (1835-1909) and his student Enrico Ferri were the leaders in the attempt to connect criminal behaviour with biological causes. Moreover, women were 
described as less evolved than men, closer to primitive nature that would not allow degeneration into criminal propensity. Women exhibiting more masculine features would be less likely to be chosen as breading mates. When women did commit crime, those crimes were of a character that required little energy and forethought. Lombroso reasoned that women's physical and intellectual abilities were inferior to those exhibited by men. Lombroso characterised short, dark haired women, women with moles and masculine features as good candidates for crime (Lombroso \& Ferrero, 1900). ${ }^{1}$

In short, Lombroso and Ferrero defined distinctive sub species of women as "good" and "bad," "natural" and "abnormal" and equated these with conformity and crime. In this they reflected nineteenth century attitudes to respectable and other women and added another footnote to the debate about 'separate spheres'. But they discussed little about female criminality and talked more about themselves and their ideas about women. (Wolf Gang, 1972). ${ }^{2}$ The theories and writings of Ceaser Lombroso, who was the leading proponent of positive criminology, have influenced the course of thinking more deeply than those of any other criminologist (Mannheim, 1965). ${ }^{3}$

Another scholar Enrico Ferri (1856-1929) expressed interest in Lombroso's ideas of basic biological causation of criminal behaviour, but he stressed the importance and interrelation of social, economic, and political factors. In his text criminal sociology, where he expanded his thought on the whole problem of crime, and presented his original thesis on its causes. Ferri believed that crime is caused by the certain factors, he classified them as: Physical (race, climate, geographic location, seasonal effects, temperature, etc). Raffaele Garofalo (1852-1934) was a positivist who rejected the doctrine of free will. He believed that crime and criminal can only be understood when studied by using scientific methods, and that science deals with universals. He, therefore, developed a sociological definition of crime that was universal and would, as stated, "designate those acts which no civilised society can refuse to recognise as criminal and repress by punishment" (Vold \& Bernard, 1986). ${ }^{4}$ Garofalo identifies four basic criminal classes. Even though they are distinct from one an other, they are related in the sense that each type is characterised by "a deficiency in the basic altruistic sentiments of pity and the probity" (Allen). ${ }^{5}$

\section{Psychological Perspectives}

Psychological theories of crime associate criminality with particular types of personality. Some have suggested that in a minority of individuals, an immoral or psychopathic personality (withdrawn, emotionless and delighting in violence) develops. Sigmund Freud (1856-1939) was the father of psychoanalysis. He was an important contributor to the theories of the development of personality. Freud linked criminality to an unconscious sense of guilt that the individual retains because of his childhood. Refering to Oedipus Complex or Electra Complex in the case of women, Freud says that a male child is attracted to and seeks affection from his mother, the female child from his father. 
During this oedipal stage of psychosexual development, as it is termed, the male child resolves his Oedipus complex by identifying with his father and sublimating his desires for his mother. By identifying with parental figures, the child internalises the standards and rules of his or her culture, and the super ego emerges (Freuds, 1933). ${ }^{6}$ Freud contributed his views about female criminality using psychiatric constructs. Freud believed that female deviance was rare. Anatomically inferior to men, women are described by Freud as culturally inferior which matches her lesser abilities. By nature and by plan, Freud claims, women are incapable of rational thought and, due to their inferiority complex are concerned with only marginal matters. Thus Freud's deviant woman is one who has wrongly adopted the wrong sex role, contrary to nature's intentions (Freuds, 1933). ${ }^{7}$

Pollak (1961) published his key work in the field of women and crime. "In the Criminality of Women," Pollak blames female criminality on biological phases that undermine a woman's natural inhibitions and influence criminal offending. Under this theory, menstruation awakens feelings of irritation and complaint about her subordinate status in society. Pregnancy leads to irritation, anxiety and emotional imbalance. Also a menopausal woman becomes frightened about her emotional security and her marital well-being. Unlike Lambroso and Freud, though, Pollak believed that female criminality was more common than publicly acknowledged. Women's superb skills of deceit and concealment resulted in their deviant acts being largely undetected by others. Pollak explained that these skills were biologically driven with social reinforcement, as represented her sexual enjoyment due to the invisibility of her orgasm (Pollak, 1961) ${ }^{8}$ Pollak saw woman as automata (Smart, 1977). ${ }^{9}$

\begin{abstract}
Abuse Theory
There are still unexamined environmental factors, which may be contributing to the increase in crimes committed by women. Abuse is one such factor. Herman (1992) explains that the adult abused, as a child will have difficulty negotiating the demands of adult life-the personality formed in an environment of coercive control is not well adapted to adult life. The survivor is left with fundamental problems in basic trust, autonomy and initiative. She approaches the tasks of early childhood establishing independence and intimacy-burdened by the major impairments in self-care, in cognition and memory, in identity, and in capacity to form stable relationships. She is still a prisoner of her childhood. Given the limited capacity of the survivor of abuse to cope with the demands of adult life, it seems plausible that women who were abused as children would be unable to negotiate the environmental stresses that were previously associated with crime. (Herman, 1992). ${ }^{10}$
\end{abstract}

Studies of female offenders highlight the importance of relationships and the fact that criminal involvement often came through relationships with family members, other 
significant people or friends (Cheseny Lind 1997, Owen and Bloom 1995, Owen, 1998), women offenders who cite drug abuse as self medication often discuss personal relationships as the cause of their pain (Pollock, 1998). This has significant implications for therapeutic interventions that deal with the impact that these relationships have on women's current and future behaviour.

\section{Theory of Trauma}

An understanding of trauma is also essential. Trauma is not limited to suffering violence, but includes witnessing violence, as well as the trauma of stigmatisation because of poverty, racism, incarceration, or sexual orientation. The vast majority of female offenders have been physically and/or sexually abused both as children and adults. Thus, most female offenders are trauma survivors when they enter the system, and then they are at risk for retraumatization by the system. Incarceration can be traumatising in its self, and the racism and classism that characterise the criminal justice system can be further traumatising. Many women use drugs or alcohol in order to medicate the pain of trauma. Trauma skews a woman's relational experience and hinders her psychological development (Herman, 1992). ${ }^{11}$

Psychiatrist J. Herman (1992) writes that trauma is a disease of a disconnection and that there are three stages in the process of healing from trauma:

1. Safety

2. Remembrance and mourning

3. Reconnection. "Survivors feel unsafe in their bodies. Their emotions and their thoughts are not in their control. They also feel unsafe in the company of other people" (Herman, 1992). ${ }^{12}$ It is also important to acknowledge that for some women and girls, their first experience of safety is in a correctional setting. Violence and abuse have been their experience at home and on the street. It is a harsh social reality when a female believes that she is safer in prison or jail (Herman, 1992). ${ }^{13}$

\section{Theory of Women's Development}

The next important element is the theory of women's psychological development (Covington \& Surrey, 1997). Traditional developmental psychology is based on a separation/individuation model. The Relational Model, developed by the Stone Centre, located at Wellesley College, posits that the primary motivation for women throughout life is not separation, but establishing a strong sense of connection. When a woman is disconnected from others, or involved in abusive relationships, she experiences disempowerment, confusion, and diminished zest, vitality and self-worth-fertile ground for addiction. Healthy, growth-fostering relationships create increased zest and vitality, empowerment, self-knowledge, self-worth and a desire for more connection. In a growth- 
fostering relationship, a woman develops a sense of mutuality that is "creative, energyreleasing and empowering for all participants," and fundamental to her psychological well being. If we are trying to create a treatment for women to help them to change, grow and recover from addictions, it is critical that they be in programs and environments where relationship and mutuality are core elements. The system needs to provide a setting where women can experience healthy relationship with their counsellors and each other. Unfortunately, the criminal justice system is designed to discourage women from coming together, trusting, speaking about personal issues or forming bonds of relationship. Women who leave prison are often discouraged from associating with others who have been incarcerated. If women are to be successfully reintegrated back into the community after serving their sentences; there must be a continuous follow-up of care that can connect them to a community after they have been released. Ideally, these community programs should have a relational basis (Gilligan, 1982). ${ }^{14}$

\section{Socio-Economic Perspectives}

Sociological theories hold that crime is based on the interconnections between conformity and deviance in different social context. Social factors and context such as wealth, power, race, ethnicity and gender, all shape the definition of deviance.

Thomas had earlier produced sex and society (1907), which was clearly influenced by Lombroso and Ferrero. Thomas, however, lived through a traditional period in the study of crime and delinquency and in his later work he was more concerned with social influences and pressures. He dealt with instincts especially the maternal instinct in women; the child is helpless throughout a period of years and would not live unless the mother was impelled to give it her devotion. Mature women and young girls suffered in the modern revolt and unrest because they were more excluded and felt most frustrated at their deprivations in costly and luxurious articles of women's wear. Thomas wrote "disorganising the lives of many who crave these pretty things" (Thomas 1923). ${ }^{15}$ The bad family life constantly evident in these pages and the consequent delinquency of children as well as crime, prostitution and alcoholism are largely due to the overdetermination of economic interests (Thomas, 1923). ${ }^{16}$

Freedman (1981) in "Their Sister's Keepers" suggests that the growing rate of women in prison between 1815 and 1860 can be linked to social change, especially urbanisation, and new agents of social control such as urban police and moral reformers. Under these influences, not only serious crimes against persons or property, but unlawful personal drunkenness' idle and disorderly conduct and vagrancy brought the majority of criminals of both sexes into the courts and prisons (Freedman 1981). ${ }^{17}$ She points out that fewer job opportunities and lower wages for women resulted in economic marginalization and increased the need for women to resort to crimes such as prostitution, especially during wars when men were not able to support their families. Prostitution was often the most 
readily available way for women to support themselves and their children. Once convicted or even suspected of a crime, a woman became even further marginalized. Women shunned anyone suspected of being a "fallen women". Because of this stigma, the female prisoner largely neglected often subjected to "over crowding, harsh treatment and sexual abuse" (Freedman, 1981). ${ }^{18}$

Box (1987) explains female crime in terms of poverty and unemployment. Women's' usual response is lack of opportunity and school failure. He argues that if they blame themselves rather than society, they are less likely to turn to crime. When they do, it is as a desperate attempt to escape from poverty rather than, as in the case of many men, an aggressive response is their social situation (Box, 1987). ${ }^{19}$

Simon and Landis (1991) pointed out that: Great participation in the labour force does not necessarily mean either more equality between the sexes or an improved economic situation for women. The bulk of female offenders, if employed at all, are concentrated in a pink-collar ghetto, and their positions are characterized by poor pay and unrewarding, insecure work. Female crime, the bulk of which is petty property crime, constitutes a rational response to poverty and economic insecurity (Simon \& Landis, 1991). ${ }^{20}$

Messerschmitt posits that the criminal justice system is not only lessening their leniency, but is also punishing women for the women's movement. Increasingly, those who do not act in a feminine way that is, those who indicate an erosion of traditional female gender roles are viewed stereotypically as nontraditional and different kinds of punishment are recommended for them.

In addition, Messerschmitt suggests that the criminal justice system publicises and exaggerates the crimes of women relative to men, which creates the impression of a larger increase in the female crime rate than what is actual (Messerschmitt, 1992). ${ }^{21}$

Daly (1993) identified five pathways to female offending:

1. The street woman, who was severely abused as a child, lives on the street, and generally ends up in court because she has been supporting her drug habit through selling drugs, prostitution, and stealing.

2. The harmed and harming woman, who was also abused as a child, but who responded with anger and "acting out" and who may have become violent through use of alcohol and /or other drugs.

3. The battered woman, who usually reaches court when she has harmed or killed a violent man with whom she is in or just ended a relationship (unlike the previous two types of women, the battered woman usually does not have a previous criminal record).

4. The drug connected woman who uses or sells drug as a result of her relationships with her male partner, children, or mother. Like the battered women, does not 
tend to have much of a criminal record. Other women commit economically motivated crimes either out of greed or poverty.

In 1993 S. K. Gosh discussed female involvement in criminal activities in his book, "Women and Crime According to Ghosh, types of crime" committed by women are; (i) crime against property, (ii) crime against person, (iii) crime against public and (iv) miscellaneous (such as boot legging smuggling, gambling, drug addiction, prostitution, etc.). Rapid urbanisation and industrialisation, new socio-economic stresses and strains, breakup of the age old institution of joint family, late marriages, free mixing of men and women, growth of films on crime and sex and wide spread circulation of pornographic literature had profound effect, when all these factors coincide, the strains prove too great for some women especially those with inherently unbalanced personalities to divert them from a law abiding life to one of crime (Ghosh, 1993). ${ }^{22}$

\section{Differential Association Theory}

E. H Sutherland (1939) developed a theory known as "differential association theory". This theory suggested that criminal behaviour is learned through association with other people, usually in the form of new groups. This learning includes both the acquisitions of attitudes towards the commission of certain acts and the learning of criminal techniques. The learning experiences (or differential associations) will vary in frequency and importance for each individual, although according to Sutherland, the learning of criminal behaviour is no different from learning of any other form of behaviour. "The process of learning criminal behaviour by association with criminal male or female and anti criminal patterns involves all of the mechanisms that are involved in any other learning" (Sutherland. 1947). ${ }^{23}$

\section{Liberation Theory}

Freda Adler's, "Sisters in Crime: The rise of the New Female Criminal", was published in 1975. Adler predicted increasing rates of female offending as a result of the emancipation of women and their growing participation in the work place. Adler argues that the feminist movement brought about progressive changes in status for women in such areas as the family, marriage, employment and social position. Women's liberation had removed restrictions on women's behaviours and opportunities.

Women no longer had to conform to male definitions of femininity opportunities. "Women have become doctors, lawyers, soldier, and Stevedores. At the same time, women have become burglars, embezzlers, and terrorists" (Adler, 1975). ${ }^{24}$ Women's liberation, Adler envisaged, created new structural opportunities for women in crime. Competition in the work place required women to adopt certain traditional masculine 
characteristics, such as assertiveness, aggressiveness, and risk taking. The same trails are associated with criminal offending.

"In the same way the women are demanding equal opportunity in fields of legitimate endeavour, a similar number of determined women are forcing their way into the world of major crimes" (Adler, 1975). ${ }^{25}$ Adler assumed:

Women's needs and ambitions are similar to men. The more the position of women in society improved the more alike their legitimate and criminal behaviour became. Women would naturally wish to emulate male patterns in criminality and would adopt masculine roles to do so (Adler, 1975). ${ }^{26}$

The typical female offender is not one who received main benefits from the liberation movement. Women criminals are generally uneducated, unskilled and commit household robbery. The liberation theory tends to ignore class and race differences among women in favour of a simplistic male / female role dichotomy (Smart, 1979). ${ }^{27}$

\section{Power Control Theory}

Power control theory, developed by John Hangan (1987) and his associates seek to explain those differentials. Hagan's view is that crime and delinquency rates are a function of two factors (1) Class position (power) and (2) Family function (control). The link between these two variables is that within the family, parents produce the power relationships they hold in the work place (Siegel, 1992). ${ }^{28}$

Power control theory argues:

1. Class position influences delinquency by controlling the quality of family life.

2. Paternalistic families control daughter in cult of domesticity and delinquency is less likely.

3. Egalitarian families have less control and more delinquency.

In the paternalistic or patriarchal family the father's experience of control over others or being controlled is reproduced in the household. His focus is directed outward towards his instrumental responsibilities, while the mother is left in charge of the children, especially their daughters. Sons are encouraged and allowed to "experiment" and take risks. Daughters in this scenario are closely monitored, so that participation in the deviant or delinquent activity is unlikely.

The egalitarian family is characterised by little difference between the mother and father's work roles so that the responsibility for child rearing is shared. Here neither child receives the close supervision present in the paternalistic family. Middle class aspirations and values dominate: mobility, success, autonomy, and risk taking. Daughters' deviance now mirrors their brothers'. This pattern seems to hold for single 
parent (female headed) households, even within the working / lower class. Here, in the absence of the father, the mother's supervision over her children is not as intense as in the paternalistic family and in fact children of both sexes may be encouraged to experiment with risk taking, instrumental roles. Power control theory, then implies that the middleclass youth of both sexes will have higher crime rates than their lower class peers (Siegel $1992)^{29}$

\section{Islamic Perspective}

Islam is very much interested in establishing a society that is pure, and is free from the filth of sin and crime, a society in which men and women would live in total freedom from fear of all kinds including fear of crime and violence. It therefore, wishes to build a society on the foundations of pity, fear of Allah, and absolute justice, in which each person would respect the rights of other people and would not trespass on them.

Let us come back to man and see how Islam protects him to help the human live in happiness and tranquility. Islam has legislated marriage. In the ideal life, according to Islam, a man has to live with his wife, and the ideal life for a woman is in living with her husband. To protect the family life Islam has forbidden the illegal sexual relation.

The Hudood ordinance is Islamic penal law. The ordinance applies to a Muslim and consist on five sections: The offence of Zina (adultery, fornication and rape): The offence of Qazf (perjury or defamation about fornication or adultery): The prohibition (of alcohol) order, the Execution of the punishment of whipping: and the offences against property. To sum up the Hudood laws affect all citizens with particular disastrous effect.

Women are discriminated by law, they find it extremely difficult to prove rape and may face criminal prosecution if they fail to do so, women who behave in ways their husbands or fathers dislike, or who seek to divorce and remarry, or who choose to marry against the will of their parents, or who happen to be related to a man wanted by the authorities and the strongly accused of Hudood offence risk criminal prosecution under the Hudood laws, often with no basis in fact. Their male co-defendants in such cases also suffer, although they are better protected by the law and benefit from its biases against women. Allah says in the Holy Quran: "The woman and the man guilty of adultery or fornication Flog each of them with a hundred stripes: Let not compassion move you in their case, in a matter prescribed by Allah, if you believe in Allah and the last Day and let a party of the Believers witness their punishments" (Al-Ahzab, 24: 2).

First to protect the mind of man, which is a part of the body, Islam prohibited use of liquor, which in turn derails one's mental status and may lead to sinful act. In addition to that, liquor is harmful for health. Therefore Islam has forbidden the consumption of all kinds of liquor. To protect the whole body of a human being, Islam has legislated capital punishment for the intentional killer, Allah says: 
"Nor take life, which Allah has made sacred, except for just cause. And if anyone is slain wrongfully we have given his heir the authority (to demand Qisas or to forgive): but let him not exceed bounds in the matter of taking life, this type of punishment seems to be very severe but I would like to tell you that this punishment is not for every sort of theft. If a person steals bread, this is not a punishable crime. Similarly if the stolen thing was not guarded and had been used as a tool of temptation the orders would be different. Caliph Hazrat Umer Bin Khitab did not cut the hands of four thieves who had stolen grain because of their hunger and need, when there was an acute famine in Arabia. (Al Nisa, 4:135).

In the light of these perspectives it is concluded that due to socio economic and psychological reasons women have been so powerless and passive that some have flipped and became more aggressive instead of more assertive. They may be committing more violent crimes as a backlash against what they view is still a male dominated society.

\section{End Notes}

${ }^{1}$ Lombroso, C. and Ferrero (1900) The female Offender, New York, Appleton, p. 152.

${ }^{2}$ Wolf Gang, 1972: 232.

${ }^{3}$ Mannheim, H. (1965) Pioneers in Criminology, Chicago, Quadrangle Banks, p. 213.

${ }^{4}$ Vold G.B. and Bernard T.J.(1986) Theoretical Criminology, New York, Oxford University Press, p.43.

${ }^{5}$ Allen, p.327.

${ }^{6}$ Freuds, S. (1933) New Introductory Lecturers on Psychoanalysis, New York, W. W. Norton, p.93.

${ }^{7}$ Ibid.,

${ }^{8}$ Pollak, 1961, p. 39) ${ }^{1}$.

${ }^{9}$ Smart, 1977, p.52

${ }^{10}$ Herman, J.L (1992) Trauma and Recovery, New York, Basic Books, p.116.

${ }^{11}$ Ibid., p.160.

${ }^{12}$ Ibid., p.160.

${ }^{13}$ Ibid., p.161. 
14 Gilligan, G. (1982) In a Different Voice: Psychological Theory of Development. Cambridge M. A, Harvard University Press, p.64.

${ }^{15}$ Thomas 1923, p.71

${ }^{16}$ Ibid., p. 256.

${ }^{17}$ Freedman, E. B. (1981) Their Sisters Keepers, Ann Arbor, The University of Michigan Press, p.14.

${ }^{18}$ Ibid., p.15.

${ }^{19}$ Box, 1987, p.197.

${ }^{20}$ Simon, R. J. and Landis, J. (1991) The Crimes Women Community the Punishments They Receive, Lexington, MA, Lexington Books, p.9.

${ }^{21}$ Messerschmitt, 1992, p.80.

${ }^{22}$ Ghosh, S.K. (1993) Women and Crime, New Delhi., Ashish Publishing House, p.183.

${ }^{23}$ Sutherland. 1947, pp.5-9.

${ }^{24}$ Adler, F. (Nov,1975) “The Interaction between Women's Emancipation and Female Criminality: A Cross-cultured Perspective" In International Journal of Criminology and Penology, p. 12.

${ }^{25}$ Ibid., p. 13

${ }^{26}$ Ibid., p.14.

${ }^{27}$ Smart, 1979, p.58.

${ }^{28}$ Siegel, L. (1992) Criminology, St. Paul, M.N, West Publishing Company, p.69.

${ }^{29}$ Ibid., p. 270.

\section{References}

Chesney-Lind, M. (1997) The Female Offenders: Girls, Women and Crime, Thousand Oaks, CA, Sage.

Daly, K. (1993) Gender, Crime and Punishment, New Haven, Vale University Press. 
The Holy Quran, Al-Ahzab, 24: 2

The Holy Quran, Al Nisa, 4:135.

\section{Bibliography}

Adler, F. (1971) The Female Offender in Philadelphia, Doctoral Dissertation, No. 72, 6127, University of Pennsylvania.

Adler, F. (1975a) Sisters in Crime: The Rise of the New Female Criminal, New York, McGraw-Hill.

Adler, F. and Simon, R.J. (1979) The Criminology of Deviant Women, Boston, Houghton Miffin.

Adler, F. Mueller, Gerhard, O.W, and Laufer, W.S (1995) Criminology, New York, McGraw Hill Inc.

Al-Farooq (2000) The Islamic Journal, Published by Jamia Farooqie Karachi Pakistan.

Babbie, Earl (1992) The Practice of Social Research, California, Belmont.

Bandura, A. (1977) Aggression: A Social Learning analysis, Englewood Cliffs, N.J, Prentice Hall.

Bandura A, Ross, D. and Ross S. (1963) "A Comparative Test of the Status, Social Power and Secondary Reinforcement Theories of Identification Learning" In Journal of Abnormal and Social Psychology.

Cheseny-Lind, M. and Sheldon, R. (1992) Girl's Delinquency and Juvenile Justice, Pacific Grove, CA, Brooks / Cool Publishing.

Farrington, D. P. (1994) "Human Development and Criminal Carriers" In M. Maguire, R. Morgan and R. Reiner (eds). The Oxford Hand book of criminology, Oxford, Claredon Press.

Hagan, J. (1987) Modern Criminology: Crime, Criminal Behaviour and its Control, New York, Mc Graw Hill Book Company.

Hanna, C. (1999) "Ganging upon Girls: Young Women and their Emerging Violence” In Arizona Law Review, vol. 41.

Hayat, A. A. (2002) Women Victims of Social Evils, Karachi, Institution Security Management. 
Khalida, G. (2000) Trafficking of Women and Children in South Asia and with in Pakistan, Karachi, A Project of LHRLA Pakistan.

Langer, E. J. (1978) "The Psychology of Chance" In Journal for the Theory of Social Behaviour.

Leonard, G.B. (1982) Women Crime and Society: A Critique of Criminology Theory, New York, Longman.

Leventhal, G. (1977) "Female Criminality: Is “Women's Lib" to Blame?" In Psychological Reports, Volume:41 Issue:3.

Libelling, A. (1994) "Suicide Among Women Prisoners" In The Howard Journal.

Lombroso, C. (1911) Crime: Its Causes and Remedies, New York, Little Brown.

Lombroso, C. and Ferrero, W. (1895) The Female Offender, London, T. Fisher unwiro.

Merton, R. K. (1965) Social Theory and Social Structure, New York, The Free Press Company.

Pollock-Byrne, J.M. (1990) Women, Prison and Crime, Pacific Grove, CA, Book/ Cole.

Ram, A. (1987) Crime Against Women, Jaipur, Rawal Publication.

Simon (Eds) (1979) The Criminology of Deviant Women, Boston, Houghton Miffin.

Tariq, N. P. (1983) Socio-Psychological Aspects of Crime in Pakistan, Islamabad, National Institute of Psychology.

Rana Saba Sultan is Associate Professor in the Department of Sociology, University of Karachi.

Irshad Bibi is Associate Professor in the Department of Sociology Islamia College, Karachi. 